\title{
MULTICRITERIAL OPTIMIZATION OF LIQUID FOOD PACKAGING SYSTEMS
}

\author{
Zs. Bogó-Tóth and Z. LAKNER* \\ Department of Food Economics, Faculty of Food Science, Budapest Corvinus University \\ H-1118 Budapest, Villányi út 35. Hungary
}

(Received: 28 April 2014; accepted: 28 July 2014)

\begin{abstract}
The food industry is in the crossfire of increasing pressure of competition, consumer demands, and growing importance of ecological sustainability considerations. Life cycle analysis is one of the most important methods for evaluation of environmental effects of food industrial technologies and packaging systems. During the last decades there have been an intense work to collect pieces of information on different environmental aspects of food packaging systems all over the world, but there is a considerable gap between the amount of knowledge and its practical application in decision making on the level of enterprises as well as in the process of determination of environmental protection fee. Application of modern, freely available software frameworks for life cycle analysis offers a favourable possibility for integration of environmental information into managerial and governmental decision making processes. Based on case studies, the article demonstrates the possibilities of utilisation of cumulative environmental burden indicators as well as expert decision-support systems for optimisation of product-portfolio, based on environmental considerations.
\end{abstract}

Keywords: life cycle analysis, NIMBUS software, open-LCA

During the last decades three main factors have been emerging, increasing the importance of food packaging system development: (1) rapid growth of long-distance food trade (BRUNELLE et al., 2014); (2) emerging of new trends in consumption patterns (FLANIGAN et al., 2013); (3) continuous effort to better utilise the possibilities of the packaging: usage of the packaging systems for promotion of products, increasing the value-added content of products by better protection, containment, information, and convenience (PASQUALINO, 2011).

At the same time there is an increasing concern on environmental aspects of human activities in general (Cook et al., 2013) and food processing in particular (TuKKER et al., 2011). In the last two decades a considerable amount of scientific knowledge has been accumulated on different environmental aspects of food packaging systems. In the opinion of Brown (1993) as well as Kroyer (1995), the environmental impact of food packaging can be seen in several ways: (a) litter; (b) usage of raw materials for packaging purposes; (c) ease and consequences of packaging disposal; (d) adverse consequences of careless disposal of packaging; (e) feasibility of recycling or reuse; (f) energy content.

SEAGER and Theis (2002) define six broad metrics of Life Cycle Assessment (hereinafter: LCA): (1) financial metrics, trying to monetarize each and every aspects of LCA components; (2) thermodynamic metrics, converting the different in- and output aspects and components into thermodynamic units, (3) environmental metrics, (4) ecological metrics, attempting to quantify the effects of production systems or services on the ecosystem functions; (5) socio-

\footnotetext{
* To whom correspondence should be addressed.

Phone/fax: +36-1-209-0961; e-mail: zoltan.lakner@uni-corvinus.hu
} 
political metrics, evaluating the different production systems in light of political and/or ethical goals of the society; (6) aggregated metrics, trying to combine the different aspects of the above mentioned approaches.

In the last three decades a considerable amount of investigations has been carried out on environmental consequences of different food packaging systems, but there has been a rather weak link between these two communities, that is why there is a considerable knowledge gap between them. This fact highlights the importance of knowledge management. One form of this is the life cycle analysis. This is an especially important problem in emerging market economies (e.g. in Hungary), where the application of LCA concepts have achieved some considerable success (Tóth-SzITA \& NÁNDORI-SIPOS, 2010), but their application is just in a rudimental phase of development (Тóth-SzITA, 2011).

The aim of the current article is twofold: (1) an integrated assessment of environmental burden, caused by different packaging systems in packaging of the same product; (2) to demonstrate the possibilities of application of data, obtained by LCA in optimisation of production-structure of a food industrial plant, based on a multi-criteria approach.

\section{Methods}

Basic principles of our research were as follows: (1) system-based approach - the application of food packaging is extremely complex, because there are different economic actors: packaging material producers, food processors, recyclers, but the life cycle analysis analyses all of these processes as a single system; (2) from cradle to grave - this refers to a holistic assessment from raw-material production to manufacture, distribution, use, and disposal, including all intervening transportation steps necessary or caused by the product's existence; (3) glass-box approach - we analyse each of the processes in detail; (4) integrated application of global knowledge base, adapted to local conditions of a well-defined geographic area: Hungary.

The most important steps of our analysis have been as follows: (1) outlining the systemboundaries for analysed food production systems. In this process, we have taken into consideration the total life cycles of food packaging system, but omitted the environmental aspects of establishment of production infrastructure as well as the environmental burden caused by food products (which is filled into the packaging); (2) determination of packaging alternatives; (3) determination of basic technological phases and parameters (e.g. number of recycling). In our case - in line with international practice (Detzel \& Böss, 2006) - we have calculated by one round of recycling and $50 \%$ of re-collection; (4) determination of environmental burden of different packaging alternatives by Open-LCA software (GreENDELTA, 2013); (5) determination of relative importance of different factors of environmental burden; (6) multiobjective analysis of different packaging technologies.

For the comparison of different factors, causing ecological consequences we have applied two approaches:

(1) first we applied the eco-factor method, developed in Switzerland nearly ten years ago (FRISCHKNECHT \& BÜSSER, 2013). The eco-factor is a measure of the environmental burden of different products and activities.

(2) another method of comparison of environmental consequences has been the expert estimation. We have involved nine specialists from fields of ecology, agriculture, and food science into analysis. All of them had a firm scientific background and international experience. 
To create an interval scale for comparison of different types of environmental burden, we have asked the respondents to carry over a Thurson-type pairwise preference test (HURST, 1955; NicoLIC, 2012). In this way, we have been able to measure (a) the consequentness of individual specialists; (b) the level of concordance between the experts; (c) the relative importance of different environmental burden factors, expressed on values of an interval scale.

Based on pairwise comparison, we have determined the weights of different ecological effects of packaging systems. Optimisation of product-portfolio with purpose to minimise the total environmental burden is a multi-objective optimisation problem, with more than one goal-function. Solving of such type of programming task is a complex task mathematically (MARLER \& ARORA, 2004). To study the possibilities of multicriterial optimisation application, we have chosen a freely available, theoretical tool: the Nimbus (Nondifferentiable Interactive Multiobjective Bundle-based Optimisation) Software (MietTinen \& MäKelä, 2006). Our aim has been to optimise the set of functions $\left\{\mathrm{f}_{1}(\mathrm{x}), \ldots \mathrm{f}_{\mathrm{k}}(\mathrm{x})\right\}$ subject to

$$
\begin{aligned}
& g_{\mathrm{j}}(x) \leq 0, j=1, \ldots, m_{\mathrm{i}} \\
& A_{\mathrm{i}} x \leq b \\
& x^{1} \leq x \leq x^{\mathrm{u}}
\end{aligned}
$$

where

$\mathrm{k}$ number of objective functions;

$\mathrm{x}$ decision variable (production of different types of packaging);

$b_{1} \quad l$ dimensional vector of maximal level of environmental burden factors;

$A_{i}$ is the matrix of environmental burden coefficients.

The solution of this equation system enables us to determine the intervals of feasible solutions for different packaging alternatives under given economic conditions.

\section{Results and discussion}

As the first step, we have been able to determine the most important characteristic features of liquid food packaging alternatives for different technologies from the point of view of their environmental burden. In this way we have obtained a large matrix, consisting of four columns (one-way glass; beverage cartoon, PET bottle, and aluminium can), and more than 500 rows, indicating the value of different pollutants. As an example, we present the environmental burden of pet bottle and aluminium can. Due to space-limitations, just one part of the results is presented in Table 1.

To make the results, obtained by this detailed analysis, comparable, we have applied the eco-point method. Results of this analysis for PET bottle and aluminium can are presented in Table 2. It is obvious, that the eco-point method is a suitable, practical approach of comparison, but it is an open-ended question, whether it is enough simply to summarise the eco-points to compare the environmental effects of different packaging technologies.

To compare the different aspects of environmental burden we have applied the pairwise preference test. From nine respondents two have not been able to give a consequent ordering (at $\mathrm{P}=0.05 \%$ level of confidence) according to the Kendall and Babington test (IIDA, 2009), so they have been excluded from the further investigations. The value of Kendall coefficient of concordance has been 0.724 , which can be considered as significant at $\mathrm{P}=0.05 \%$ level of confidence. 
Table 1. Environmental effects of alu-can and PET-bottle (example-abstract, values in $\mathrm{kg}$ for $1 \mathrm{~kg}$ packaging material, contamination of air)

\begin{tabular}{|c|c|c|c|c|c|}
\hline Components & Alu-can & PET-bottle & Components & Alu-can & PET-bottle \\
\hline $\begin{array}{l}\text { 2-Chloro-1- } \\
\text { phenylethanone }\end{array}$ & $2.76 \mathrm{E}-12$ & $9.68 \mathrm{E}-14$ & $\begin{array}{l}\text { BTEX (Benzene Toluene } \\
\text { Ethylbenzene and Xylene). } \\
\text { unspecified ratio }\end{array}$ & $3.82 \mathrm{E}-06$ & $2.88 \mathrm{E}-06$ \\
\hline Acenaphthene & $1.55 \mathrm{E}-11$ & $9.5 \mathrm{E}-12$ & Butadiene & $5.99 \mathrm{E}-11$ & $2.3 \mathrm{E}-11$ \\
\hline Acenaphthylene & $7.57 \mathrm{E}-12$ & $4.66 \mathrm{E}-12$ & Cadmium & $2.16 \mathrm{E}-09$ & $1.23 \mathrm{E}-09$ \\
\hline Acetaldehyde & $1.4 \mathrm{E}-09$ & $4.6 \mathrm{E}-10$ & Carbon dioxide & 0.001626 & $6.66 \mathrm{E}-05$ \\
\hline Acetic acid & & $1.38 \mathrm{E}-08$ & Carbon dioxide, biogenic & $8.29 \mathrm{E}-05$ & 0.001887 \\
\hline Acetophenone & $5.92 \mathrm{E}-12$ & $2.07 \mathrm{E}-13$ & Carbon dioxide, fossil & 0.244195 & 0.111434 \\
\hline Acrolein & 8.87E-09 & $5.45 \mathrm{E}-09$ & Carbon disulfide & $5.13 \mathrm{E}-11$ & $1.8 \mathrm{E}-12$ \\
\hline $\begin{array}{l}\text { Aldehydes } \\
\text { unspecified }\end{array}$ & $3.45 \mathrm{E}-08$ & $6.38 \mathrm{E}-08$ & Carbon monoxide & 0.001629 & $1.7 \mathrm{E}-06$ \\
\hline Ammonia & 8.92E-09 & $9.47 \mathrm{E}-08$ & Carbon monoxide, fossil & $9.15 \mathrm{E}-05$ & $3.66 \mathrm{E}-05$ \\
\hline $\begin{array}{l}\text { Ammonium } \\
\text { chloride }\end{array}$ & $8.45 \mathrm{E}-09$ & $5.37 \mathrm{E}-08$ & Carbonyl sulphide & $2.69 \mathrm{E}-05$ & \\
\hline Anthracene & $6.36 \mathrm{E}-12$ & $3.91 \mathrm{E}-12$ & CFCs and HCFCs, unspecified & $2.88 \mathrm{E}-06$ & $5.4 \mathrm{E}-16$ \\
\hline Antimony & $5.45 \mathrm{E}-10$ & $3.35 \mathrm{E}-10$ & Chloride & $6.35 \mathrm{E}-14$ & $1.45 \mathrm{E}-12$ \\
\hline Arsenic & $1.34 \mathrm{E}-08$ & 7.89E-09 & Chlorine & $4.32 \mathrm{E}-07$ & $5.4 \mathrm{E}-14$ \\
\hline Benzene & $7.86 \mathrm{E}-08$ & $2.65 \mathrm{E}-08$ & Chloroform & $2.33 \mathrm{E}-11$ & $8.16 \mathrm{E}-13$ \\
\hline Benzene, chloro- & $8.69 \mathrm{E}-12$ & $3.04 \mathrm{E}-13$ & Chromium & 8.84E-09 & $5.24 \mathrm{E}-09$ \\
\hline Benzene, ethyl- & $3.71 \mathrm{E}-11$ & $1.3 \mathrm{E}-12$ & Chromium VI & $2.39 \mathrm{E}-09$ & $1.47 \mathrm{E}-09$ \\
\hline $\begin{array}{l}\text { Benzo(a) } \\
\text { anthracene }\end{array}$ & $2.42 \mathrm{E}-12$ & $1.49 \mathrm{E}-12$ & Chrysene & $3.03 \mathrm{E}-12$ & $1.86 \mathrm{E}-12$ \\
\hline Benzo(a)pyrene & $1.15 \mathrm{E}-12$ & $7.08 \mathrm{E}-13$ & Chrysene, 5-methyl- & $6.67 \mathrm{E}-13$ & $4.1 \mathrm{E}-13$ \\
\hline $\begin{array}{l}\text { Benzo(b.j.k) } \\
\text { fluoranthene }\end{array}$ & $3.33 \mathrm{E}-12$ & $2.05 \mathrm{E}-12$ & Cobalt & $7.24 \mathrm{E}-09$ & $2.75 \mathrm{E}-09$ \\
\hline $\begin{array}{l}\text { Benzo(ghi) } \\
\text { perylene }\end{array}$ & $8.18 \mathrm{E}-13$ & $5.03 \mathrm{E}-13$ & Copper & $1.21 \mathrm{E}-10$ & $3.63 \mathrm{E}-11$ \\
\hline Benzyl chloride & $2.76 \mathrm{E}-10$ & $9.68 \mathrm{E}-12$ & Cumene & $2.09 \mathrm{E}-12$ & $7.33 \mathrm{E}-14$ \\
\hline Beryllium & $7.17 \mathrm{E}-10$ & $4.16 \mathrm{E}-10$ & Cyanide & $9.87 \mathrm{E}-10$ & $3.46 \mathrm{E}-11$ \\
\hline
\end{tabular}

Source: Own calculations, based on OpenLCA output

Transforming the values to an interval scale, we have determined the relative importance of different environmental factors (Table 3). It is obvious, that the experts have attached the highest importance to the greenhouse gas emission, and the relatively lowest weight to marine ecotoxicity. This can be explained by the fact that, under Hungarian conditions, even the relatively well-informed decision makers do not face with problems of environmental pollution of the world sea. 
Table 2. Eco-factors of alu-can and PET bottle (values for $1 \mathrm{~kg}$ packaging materials)

\begin{tabular}{llllll}
\hline Components & Alu-can & PET bottle & Components & Alu-can & PET bottle \\
\hline $\begin{array}{l}\text { PAH, polycyclic aromatic } \\
\text { hydrocarbons }\end{array}$ & 0.052544 & $1.39 \mathrm{E}-06$ & Fluoranthene & $4.95 \mathrm{E}-05$ & $3.04 \mathrm{E}-05$ \\
$\begin{array}{l}\text { CFCs and HCFCs } \\
\text { unspecified }\end{array}$ & 0.024481 & $4.59 \mathrm{E}-12$ & $\begin{array}{l}\text { Methane dichloro- } \\
\text { HCC-30 }\end{array}$ & $1.79 \mathrm{E}-06$ & $8.82 \mathrm{E}-07$ \\
$\begin{array}{l}\text { BTEX (Benzene Toluene } \\
\text { Ethylbenzene and Xylene) }\end{array}$ & 0.007637 & 0.005752 & Phenol & $4.61 \mathrm{E}-05$ & $4.24 \mathrm{E}-07$ \\
Carbon monoxide & 0.001173 & $1.22 \mathrm{E}-06$ & Mercury & & $1.91 \mathrm{E}-05$ \\
Cadmium & 0.000995 & 0.000564 & Icosane & $4.36 \mathrm{E}-05$ & $2.2 \mathrm{E}-05$ \\
Mercury & 0.000878 & 0.000345 & m-Xylene & $1.96 \mathrm{E}-05$ & $1.46 \mathrm{E}-05$ \\
Carbon dioxide & 0.000748 & $3.07 \mathrm{E}-05$ & Chromium & $1.52 \mathrm{E}-05$ & $2.72 \mathrm{E}-06$ \\
Hydrogen fluoride & 0.00067 & $9.5 \mathrm{E}-05$ & Sulfur & $1.05 \mathrm{E}-05$ & $7.07 \mathrm{E}-06$ \\
Lead & 0.000342 & 0.000183 & Hexanoic acid & $7.61 \mathrm{E}-06$ & $5.69 \mathrm{E}-06$ \\
Fluoride & 0.000178 & $1.81 \mathrm{E}-05$ & Silver & $4.99 \mathrm{E}-06$ & $3.73 \mathrm{E}-06$ \\
Arsenic & 0.000134 & $7.89 \mathrm{E}-05$ & Lead-210/kg & $2.94 \mathrm{E}-20$ & $2.2 \mathrm{E}-20$ \\
Furan & 0.000117 & $6.7 \mathrm{E}-05$ & TOC. Total Organic & 0 & $2.49 \mathrm{E}-07$ \\
\hline & & & Carbon & & \\
\hline
\end{tabular}

Source: Own calculations, based on data from Table 1 and FrischKNECHT \& BüsSER (2013)

Table 3. Relative importance of ecologic burden factors, caused by different packaging materials, measured on interval scale

\begin{tabular}{lc}
\hline Ecological burden type & Relative importance \\
\hline Acidification potential & 70 \\
Greenhouse gas emission & 86 \\
Terrestrial euthrophication potential & 48 \\
Aquatic euthrophication potential & 21 \\
Freshwater aquatic ecotoxicity & 64 \\
Human toxicity & 85 \\
Marine aquatic toxicity & 17 \\
Stratospheric ozone depletion & 34 \\
Terrestrial ecotoxicity & 34 \\
Photochemical oxidation & 25 \\
\hline
\end{tabular}

Source: own calculations

To determine the optimal production structure of an actual food processing plant, we have applied the cumulated data on greenhouse gas emission, photochemical oxidation, acidification potential as well as euthrophication potential obtained by Detzel and Böss (2006).

Greenhouse gas emission ( $\mathrm{kg} \mathrm{CO}_{2}$ equiv/1 litre product) function

$$
95 \times x_{1}+170 \times x_{2}+220 \times x_{3} \rightarrow \text { min. }
$$

photochemical oxidation (g ethene equiv./1 litre product) function

$$
34 \times x_{1}+15 \times x_{2}+20 \times x_{3} \rightarrow \text { min. }
$$


acidification potential ( $\mathrm{g} \mathrm{SO}_{2}$ equiv./1 litre product)

$$
318 \times \mathrm{x}_{1}+455 \times \mathrm{x}_{2}+365 \times \mathrm{x}_{3} \rightarrow \min .
$$

terrestrial euthrophication potential ( $\mathrm{g} \mathrm{PO}_{4}$ equiv./1 litre product)

$$
28 \times \mathrm{x}_{1}+11 \times \mathrm{x}_{2}+35 \times \mathrm{x}_{3} \rightarrow \min \text {. }
$$

aquatic euthrophication potential $\left(\mathrm{g} \mathrm{PO}_{4}\right.$ equiv./litre product)

$$
18 \times \mathrm{x}_{1}+8 \times \mathrm{x}_{2}+25 \times \mathrm{x}_{3} 1085.0 \rightarrow \text { min. }
$$

profit rate (HUF/l product)

$$
25 \times \mathrm{x}_{1}+14 \times \mathrm{x}_{2}+31 \times \mathrm{x}_{3} \rightarrow \max .
$$

Based on a multicriterial analysis, in first round we had been able to determine the boundaries of scope of decision-making (feasible sets, determined by ideal values and nadirs). Within these limits we have weighted the importance of different goal-functions according to weights, determined by Table. In case of $1000 \mathrm{t}$ production, if the demand for products in beverage carton ( $\mathrm{x}_{\mathrm{bc}}$ ) can be described by: $\left\{30 \leq \mathrm{x}_{\mathrm{bc}} \geq 55\right\}$, one way glass-bottle $\left(\mathrm{x}_{\mathrm{g}}\right):\left\{15 \leq \mathrm{x}_{\mathrm{g}}\right.$ $\geq 45\}$, and PET bottle $\left(x_{\mathrm{p}}\right):\left\{17 \leq \mathrm{x}_{\mathrm{g}} \geq 58\right\}$, taking into considerations the equations $4-9$, there are four solutions (Table 4).

Table 4. Four feasible (Pareto-optimal) solutions for problems, determined by equations 4-9

\begin{tabular}{lcccc}
\hline Factors & Alternative No.1 & Alternative No.2 & Alternative No.3 & Alternative No.4 \\
\hline Greenhouse gas emission & 17387 & 15777 & 9823 & 9140 \\
Photochemical oxidation & 2645 & 2819 & 1829 & 1585 \\
Acidification potential & 40852 & 338765 & 24857 & 22570 \\
Terrestrial euthrophication & 2832 & 2869 & 1801 & 1600 \\
potential & & & 1214 & 1085 \\
Aquatic euthrophication & 1942 & 1942 & 1666 & 1487 \\
potential & 2645 & 2645 & 37 & 30 \\
Profitability & 43 & 55 & 15 & 15 \\
Combined beverage carton & 30 & 22 & 17 & 17 \\
One-way glass bottle & 37 & 31 & & \\
PET package & & & & \\
\hline
\end{tabular}

Source: own calculations

\section{Conclusions}

As a result of our research we have been able to prove, that the application of open-source LCA software offers a favourable possibility to life-cycle analysis even under conditions of relatively low level of resource endowment. Results of LCA in itself cannot be used in a direct way for the practical decision-making process, because comparison of different environmental burdens needs a further consideration. This comparative analysis should be based on modern methods of application of decision support systems. Results of analysis should form a sound basis for product-portfolio optimisation, which - in itself - is a multicriterial process. Comparing different packaging alternatives, our results prove that 
(1) the achievable profit is considerable determined by the regulations, set to environmental burden of different packaging alternatives; (2) approximately the same environmental burden can be achieved by considerably differing production structures.

As a summary it can be stated that the multiobjective optimisation should be considered as a necessary tool in estimation of the optimal product portfolio at the level of enterprises and for the fine-tuning of regulatory environment on level of governmental policy.

Research has been supported by OTKA 81594 project.

\section{References}

Brown, D. (1993): Plastics packaging of food products: the environmental dimension. Trends Food Sci. Tech., 4, 294-300.

Brunelle, T., Dumas, P. \& Souty, F.O. (2014): The impact of globalization on food and agriculture: The case of the diet convergence. J. Environ. Develop., 23, 15-40.

Cook, J., Nuccitelli, D., Green, S. A., Richardson, M., Winkler, B.R., Painting, R., Way, R., Jacobs, P. \& Skuce, A. (2013): Quantifying the consensus on anthropogenic global warming in the scientific literature. Environ. Res. Lett., 8, 024024.

Detzel, A. \& Böss, A. (2006): Ökobilanzer Vergleich von Getränkekartons und PET-einwegflaschen. IFEU, Heidelberg, 145 pages.

Flanigan, L., Frischinecht, R. \& Montalbo, T. (2013): An analysis of life cycle assessment in packaging for food \& beverage applications. United Nations Environment Programme and SETAC, Milan, 88 pages.

FrischKneCht, R. \& Büsser, S. (2013): Swiss eco-factors 2013 according to the ecological scarcity method. Schweizerische Eidgenossenschaft: Federal Office for the Environment, Bern, 256 pages.

Greendelta, G. (2013): OpenLCA 1.3. (available at: http://www.openlca.org/web/14826/4, last accessed: $01.02 .2014)$

Hurst, P. (1955): L.L. Thurstone and the science of human behaviour. Science, 122, 1259-1260.

IIDA, Y. (2009): The number of circular triads in a pairwise comparison matrix and a consistency test in the AHP. J. Oper. Res. Soc. Jpn., 52, 174-185.

Kroyer, G.T. (1995): Impact of food processing on the environment”: an overview. LWT-Food Sci. Technol., 28, $547-552$.

Marler, R.T. \& Arora, J.S. (2004): Survey of multi-objective optimization methods for engineering. Struct. Multidiscip. O., 26, 369-395.

Miettinen, K. \& MäKelÄ, M.M. (2006): Synchronous approach in interactive multionbjective optimization. Eur. J. Oper. Res., 170, 909-922.

Nicolic, D. (2012): Non-parametric detection of temporal order across pairwise measurements of time delays. J. Comput. Neurosci., 22, 5-19.

Pasqualino, J., Meneses, M. \& Castells, F. (2011): The carbon footprint and energy consumption of beverage packaging selection and disposal. J. Food Eng., 103, 357-365.

Seager, T.P. \& Theis, T.L. (2002): A uniform definition and quantitative basis for industrial ecology. J. Clean. Prod., 10, 225-235.

Tо́тн-Szita, K. (2011): Life cycle assessment and sustainability. Economica, 3, 6-19.

Tóth-Szita, K. \& NÁndori-Sipos, E. (2010): A regional evaluation of sustainability with special regard to social aspects. Club of Economics in Miskolc: Theory, methodology, practice.1, 75-80.

Tukker, A., Goldbohm, R.A., De Koning, A., Verheijden, M., Kleijn, R., Wolf, O., Pérez-Dominguez, I. \& RuedaCantuche, J.M. (2011): Environmental impacts of changes to healthier diets in Europe. Ecol. Econ., 70, $1776-1788$. 